\title{
V1 Aprimoramento da produção do vírus da febre amarela em biorreatores de tanque agitado de 3 Litros
}

Marlon Vicente da Silva ${ }^{1}$, Diogo Araujo de Mattos ${ }^{1}$, Marta Cristina de Oliveira Souza $^{1}$, Andréa Nazaré Monteiro Rangel da Silva ${ }^{1}$, Sheila Barbosa de Lima1, Leda dos Reis Castilho², Luciane Pinto Gaspar', Elena Siqueira Campos Caride ${ }^{1}$, Marcos da Silva Freire ${ }^{1}$

${ }^{1}$ Bio-Manguinhos

2 UFRJ

Introdução: A febre amarela é doença endêmica em grande parte da América do Sul e da África sub-sahariana. É causada pelo vírus da febre amarela (YFV), do gênero Flavivirus e da família Flaviviridae, que é transmitido por mosquitos, principalmente dos gêneros Aedes ou Haemagogus.

Objetivo: A atual vacina disponível contra febre amarela consiste de vírus vivo atenuado, conferindo boa proteção, com efeito duradouro e bom perfil de eficácia e segurança. No entanto, desde os anos 1990, foram observados casos de reações adversas graves, principalmente depois de campanhas de vacinação em larga escala. Sendo produzida em ovos embrionados de galinha, uma tecnologia que pouco se modificou desde sua criação nos anos 1930, possui algumas desvantagens, como a alta demanda de ovos embrionados livres de patógenos e altas concentrações de proteínas do embrião de galinha na formulação final. Além disso, sua produção é lenta, laboriosa e com difícil escalonamento, o que requer a formação de grandes estoques estratégicos para casos de epidemias. Assim, é relevante o desenvolvimento de uma vacina contra febre amarela.

Metodologia: Em trabalhos anteriores, foram descritos cultivos de células Vero e propagação do YFV em spinners e biorreatores em meio de cultivo livre de soro fetal bovino, com boa obtenção de YFV ao final do processo (títulos virais $\approx 108 \mathrm{pfu} / \mathrm{mL}$ ) em volumes de trabalho de até $1 \mathrm{~L}$. Uma vez demonstrada a prova de conceito da produção do YFV em cultivos celulares em escala de bancada, o desafio seguinte é a ampliação de escala, mantendo-se a consistência observada nas bateladas iniciais de $\leq 1 \mathrm{~L}$ de volume de trabalho. No presente trabalho, descrevemos o método empregado para operação de biorreatores com vasos de 3 litros, em que se utilizou um protocolo aprimorado de cultivo, com adição gradual de meio de cultivo até a capacidade volumétrica total dos vasos, com objetivo de se diminuir a formação de espuma e agregados de microcarregadores nos vasos. A concentração de microcarregadores empregada também foi reduzida, de modo a repetir a razão células/cm2 praticada nos cultivos estacionários do préinóculo. 
Resultados: A execução de três bateladas de produção do YFV sob as condições do protocolo aprimorado nos forneceu resultados satisfatórios quanto à consistência da cinética de crescimento celular e produtividade específica do vírus, tendo-se atingido satisfatória densidade celular no momento da infecção viral (>106 céls $/ \mathrm{mL}$ ) e títulos virais semelhantes $(\approx 108 \mathrm{pfu} / \mathrm{mL})$ ao processo na escala de $1 \mathrm{~L}$.

Conclusão: Estes resultados corroboram a possibilidade da produção do YFV em biorreatores após o incremento de escala testado, sem efeitos deletérios na produtividade específica.

Palavras-Chave: Febre Amarela, Biorreatores, Células Vero 